\title{
sciendo
}

\section{A Comparative Analysis of Crowdfunding in Poland and Romania}

\author{
Mina FANEA-IVANOVICI \\ The Bucharest University of Economic Studies, Bucharest, Romania \\ mina.ivanovici@economie.ase.ro
}

PICBE | 182

\author{
Małgorzata SIEMIONEK-RUSKAŃ \\ University of Gdansk, Gdansk, Poland \\ m.siemionek@gmail.com
}

\begin{abstract}
Given the difficulty to access traditional bank funding by creative businesses and start-ups, crowdfunding as an alternative way to finance innovative and creative projects has been adopted, enacted and successfully used by several Western countries, which can serve as best practice examples. However, in many countries crowdfunding is still an emerging phenomenon due to its novelty and variety, the general awareness regarding this alternative funding method being relatively low. The aim of this paper is to investigate the extent to which Poland and Romania, the two largest Central and Eastern European member states, have adopted and used crowdfunding to support innovative and creative projects and to assess the sustainability of such a novel funding method in the respective countries. The objective of the comparative analysis is to determine how the existing legal framework supports the implementation of crowdfunding activities and what crowdfunding types are being used in each country based on the existing local crowdfunding platforms, to identify and explain the main strengths and weaknesses of each of the two markets, as well as to provide a set of measures and proposals that can be adopted by the two countries in order to promote and enhance the crowdfunding phenomenon, which we argue is a factor that ensures business sustainability in creative and innovative activities carried out especially by start-up companies. Apart from the empirical analysis of legislation and platforms, the research methodology includes a survey among business students and fresh graduates of business schools, the purpose of which being to assess the level of awareness of young entrepreneursto-be regarding this funding method.
\end{abstract}

Keywords: crowdfunding, start-ups, creative industries, Poland, Romania, crowdfunding platforms.

\section{Introduction}

Crowdfunding has emerged as an alternative financing source both for supporting business projects with limited or no traditional banking ineligibility, especially start-ups and creativecultural industries, and for supporting various social, humanitarian or environmental nonprofit causes and projects. It has become an alternative funding method to support innovative and creative projects, whose viability has been tested predominantly in countries where it was adopted, enacted, promoted and successfully used, i.e. United States (US) and Western European countries. Such countries can serve as best practice examples for all the other countries where crowdfunding is still in its early days.

World and European statistics do no place Central and Eastern European (CEE) European Union (EU) member states among the best performing countries in terms of crowdfunding. With very few exceptions, CEE EU countries lag behind in terms of crowdfunding development and positions in world rankings. Thus, in this paper we depart from the hypotheses that in CEE EU countries crowdfunding is still a far-from-reachingmaturity emerging phenomenon and that the level of awareness of the public about this 
funding method is relatively low. In such a context, the purpose of this research is to investigate the extent to which Poland and Romania, the two largest CEE EU member states have adopted and used crowdfunding to support innovative and creative projects and to assess the sustainability of such a novel funding method in the respective countries. The objective of the comparative analysis is to determine how the existing legal framework supports the implementation of crowdfunding activities. We will also look at the crowdfunding types that are being used in each country based on the existing local crowdfunding platforms. Based on these findings, we will further identify and explain the main strengths and weaknesses of each of the two markets, and we will provide a set of measures and proposals that can be adopted by the two countries in order to promote and enhance the crowdfunding phenomenon, which we argue is a factor that ensures business sustainability in creative and innovative activities carried out especially by start-up companies. Apart from the empirical analysis of legislation and platforms, the research methodology includes a survey among business students and fresh graduates of business schools in both countries, the purpose of which being to assess the level of awareness of young entrepreneurs-to-be regarding this funding method.

\section{Literature review}

Crowdfunding is an alternative type of finance in which the backing community and project initiators in need of finance are reunited via dedicated online platforms called crowdfunding platforms (European Commission, 2018). Project initiators launch online calls for finance for their projects by describing the product or service to be obtained and presenting arguments for supporting the project, the time frame, the necessary amount of money to be raised, other additional sources of finance used, the duration of the campaign and the stake of the community for supporting the project.

Crowdfunding has evolved from its initial primary forms: reward-based crowdfunding and donation-based crowdfunding to more complex financial instruments, such as equity-based crowdfunding, lending-based crowdfunding, invoice trading crowdfunding and other hybrid types. Countries or markets with little experience and a low level of penetration of crowdfunding mostly use the first two types, in which the backer either receives a non-financial reward for their contribution (a good, service or experience along with public acknowledgements) or no reward at all. The more developed forms of crowdfunding turn the backer into an investor, who is entitled to receive profit shares from the company and to become a shareholder, a creditor, who earns interest or a party purchasing receivables from the project initiator.

Crowdfunding is a method for funding a variety of new ventures, allowing individual founders of for-profit, cultural, or social projects to request funding from many individuals (Mollick, 2014). Unlike other fundraising campaigns, crowdfunding implies the use of internet and is based on the social media influence due to the capacity of the latter to generate audience. In addition, crowdfunding can generate further benefits by providing a marketing channel, through which entrepreneurs gain visibility and can communicate (Gascon et al, 2015). Thus, it can help entrepreneurs test their ideas with the support of the public, with whom they get into a direct relationship (Hossain \& Oparaocha, 2017). In addition, the crowdfunding campaign can be an opportunity to test the idea or project before its launch, such feedback often leading to the improvement of the final product; the resulting network 
can also contribute with capital, technology, market knowledge and useful interaction (Nucciarelli et al., 2017). Crowdfunding implies a double switching behaviour: first, entrepreneurs move from traditional banking financing towards crowdfunding for reasons like speed, flexibility, simplicity, process transparency; second, the community diversifies investment options being motivated by a reward or the expected gains (Maier, 2016). Increased transparency, entrepreneur's ethics and speed of reaction on crowdfunding platforms can enhance the herding behaviour of the community (Porlezza \& Splendore, 2016; Baucus \& Mitteness, 2016; Farajian et al., 2015). Therefore, crowdfunding platform owners should provide all contractual details and updated financial information in real time. Renwick and Mossialos (2017) argue that accountability of project initiators is fostered in crowdfunding projects, but fraud still remains a barrier in crowdfunding development, along with adverse selection and moral hazard.

The European Commission (2016) reveals that the most developed crowdfunding market is that of the US, followed by Asia and Europe. The world market has increased in an accelerated way, with a rise of 167\% worldwide being recorded during the year 2013-2014 - the US market increased by 145\% and Asia by 320\%. Between 2014 and 2015, the world market rose by 28\%, while the year 2015-2016 brought about a slight decrease of 3\%. In 2015, EU crowdfunding platforms raised 4.2 billion EUR, of which $98 \%$ from crowdfunding models yielding some kind of financial gain. In 2016, the most numerous platforms in Europe were functioning in Great Britain (143), France (77) and Germany (65); the largest number of platforms were reward-based (30\%), followed by equity-based (23\%) and lending-based (21\%). In 2016, the UE crowdfunding market reached 7.67 billion EUR. In 2017, an amount of 34 billion USD was raised via crowdfunding worldwide (Statista, 2018a).

For the year 2016, Poland is the top CEE EU country in terms of reward-based crowdfunding, raising 3.34 million EUR and in terms of equity-based crowdfunding, with 0.9 million EUR (Statista, 2018b, c). The real estate crowdfunding CEE market is led by Estonia (with 6.09 million EUR in 2016 and 2.35 million EUR in 2015). In this market, Poland raised 0.38 million EUR in 2015 (Statista, 2018d).

The originality of the paper stands in the analysis of two CEE crowdfunding markets, which present among the highest potential in the region due to the fact that the two largest CEE EU countries have been selected for the study. The extant literature is poor in terms of country-comparison crowdfunding analysis.

\section{Methodology}

The research hypotheses of the paper are the following: crowdfunding in Poland and Romania is still a far-from-reaching-maturity emerging phenomenon and the level of awareness of the public about this funding method is relatively low. These two hypotheses will be checked by analysing the market in each of the two countries as follows: first, by looking into the legislative progress in this matter, the existing types of crowdfunding and the number of active platforms and second, by conducting a survey among survey among business students and fresh graduates of business schools, the purpose of which being to assess the level of awareness of young entrepreneurs-to-be regarding this funding method. The paper ends by identifying the main strengths and weaknesses of each of the two markets, and by providing a set of measures and proposals that can be adopted by the two countries in order to promote and enhance the crowdfunding phenomenon. 


\section{Results and discussions \\ Enacting Crowdfunding}

There are no direct regulations on crowdfunding activities in Poland. The framework for crowdfunding transactions is still the Polish Commercial Companies Code and several acts. (European Commission, 2017). Equity-based crowdfunding and lending-based crowdfunding activities may trigger the application of financial regulations.

PICBE $\mid 185$

The crowdfunding activity is regulated by the Polish Trading in Financial Instruments Act. There are different legislation procedures regarding issuing shares in a company. In April 2018 the limit for issuing shares in a company without prospectus requirement was set to 1,000,000 Euro (as per article 6, paragraph 4, Polish Trading in Financial Instruments Act). All of the EU member states implemented the same limit in July 2018. The raise of capital will impact the increase in equity-based crowdfunding activities not only for start-ups but also for companies in their expansion phase.

Strengthening of the development of start-ups in Poland as well as increasing their competitiveness in the marketplace were key factors for introducing new type of company in Poland. In February 2019 the project of amended Commercial Code is scheduled to be reviewed by the Council of Ministers. If it is approved, that means that in the year 2020 it will be possible to open a simple joint-stock company in Poland. This is a remarkable step towards increasing elasticity in using alternative funding source for companies. It is intended to satisfy the needs of start-ups by offering specific features such as 1 PLN capital requirement or a one-person board (https://biznes.gazetaprawna.pl).

Donation-based crowdfunding and reward-based crowdfunding types are both treated as donation from a legal and fiscal point of view. These two types are regulated by the Public Fundraising Act and by the Act of Providing Services by Electronic Means.

On January 1, 2019, new tax regulations came into force in Poland. The new laws impose a number of income tax changes, including the introduction of a new mechanism allowing a significant reduction in taxation of income derived from intellectual property rights, known as the "Innovation Box". The taxation level of income from intellectual property rights is hereby lowered to 5\% (www.rp.pl). Such specific changes could trigger investment increase in certain other fields, including crowdfunding.

In Romania, the crowdfunding activity has not been enacted yet, either. This is why this financing method cannot be used in its more developed forms (equity-based, lendingbased), being limited to donation-based and reward-based types. Although these two types are different, they are both treated as donations from a legal and fiscal point of view. The most frequently used type of crowdfunding is the reward-based.

Despite the progress made toward the enactment of crowdfunding, the Bill no. $801 / 2015$ - Bill on the development of crowdfunding did not pass. The bill was meant to regulate equity-based crowdfunding. In the rationale of the bill, it is mentioned that "certain segments of the economy, such as social enterprises and the cultural-creative sector do not have solutions adapted to their needs, given their specific features, such as their social objectives or dependence on intangible assets and increased market demand uncertainty (...) [crowdfunding] introduces competition with other sources of finance as it is a method often used in innovative, artistic and social projects, it promotes innovation, culture and social entrepreneurship" (Lower House, 2015). Thus, the bill is justified both by such benefits of crowdfunding, but also by the limited access to finance of Romanian small and medium-sized 
enterprises (SMEs) and by the commitments of the government of Romania stemming from the agreements concluded with the International Monetary Fund (IMF), the European Commission and the World Bank. Such commitments include taking the necessary measures to diversify the financing sources for SMEs. The same bill mentions that "this financing source has extended on a large scale once with the global financial crisis, while the banking loan granting activities diminished and access to finance became more and more difficult". The bill was supposed to regulate the way crowdfunding platforms operate and to create the necessary legal framework to secure investors' protection. The bill proposed that project initiators can be only companies both for equity and lending-based crowdfunding types and would carry out their activity under the supervision of the Financial Surveillance Authority. Crowdfunding would imply the issuance of shares or bonds for equity-based crowdfunding entitled to receive a share of the profit or receivable titles for lending-based crowdfunding, the latter yielding interests.

The bill is quite restrictive in that project initiators can only be Romanian legal persons, while the money can only be transferred into bank accounts opened in Romania. In other words, Romanian platforms could not host projects originating from legal entities outside Romania, which is contrary to the FinTech European action plan. The European plan intends to increase the internationalisation degree of crowdfunding as well as the number of cross-border finance. The bill also imposes that the financing principle be "all or nothing" - if the project does not succeed to raise the target amount, the project initiator cannot keep the funds and has to reimburse them.

Alongside the FinTech European Action Plan, the European Commission published in March 2018 a proposal for an EU Crowdfunding Regulation. This will enable Crowdfunding platforms to provide their services both at home and in other EU Member States according to the same rules.

In short, both countries lack a specific legislation regarding crowdfunding activity. However, Polish legislation has become more flexible to accommodate alternative financing sources - as evidence stand the relatively diversified crowdfunding market in this country.

\section{An Overview of the Polish and Romanian Crowdfunding Market}

In Poland a number of 21 platforms are currently operating, as shown in Table 1.

Table 1. List of Crowdfunding platforms in Poland

\begin{tabular}{|c|c|c|}
\hline & Platform & Type of Crowdfunding \\
\hline 1 & Beesfund.com & \multirow{6}{*}{ equity } \\
\hline 2 & Crowdangels.pl & \\
\hline 3 & Crowdway.pl & \\
\hline 4 & Findfunds.pl & \\
\hline 5 & Stockrocket.pl & \\
\hline 6 & Wspolnicy.pl & \\
\hline 7 & Polakpotrafi.pl & donation and reward \\
\hline 8 & Zrzutka.pl & \multirow{4}{*}{ donation } \\
\hline 9 & \begin{tabular}{|l|} 
Siepomaga.pl \\
\end{tabular} & \\
\hline 10 & Pomagam.pl & \\
\hline 11 & Pomagamy.im & \\
\hline
\end{tabular}




\begin{tabular}{|l|l|l|}
12 & Wspolnyprojekt.pl & \\
\hline 13 & Wspieram.to & \\
\hline 14 & Wspieramkulture.pl & \multirow{2}{*}{ reward } \\
\hline 15 & zagramw.to & \\
\hline 16 & Patronite.pl & \\
\hline 17 & odpalprojekt.pl & \\
\hline 18 & Mzuricfi.pl & \multirow{2}{*}{ real estate } \\
\hline 19 & Sharevestors.com & \\
\hline 20 & Faktorama.pl & invoice trading \\
\hline 21 & Kokos.pl & lending \\
\hline
\end{tabular}

PICBE | 187

Source: Authors' own research

The Polish platforms address different types of public and have different features:

- Six platforms are equity-based crowdfunding

- The biggest Polish crowdfunding platform is Polak.potrafi.pl, which uses rewardbased and donation-based crowdfunding

- Two platforms are involved in real estate crowdfunding projects

- Four platforms are donation based crowdfunding, mostly involved in charity

- Three platforms are involved in cultural projects

- One platform is involved in board games (zagramw.to).

In 2018, some significant changes were undertaken in Poland regard crowdfunding activities. In January, the Polish biggest peer-to-peer lending crowdfunding platform, Kokos.pl, limited their activities only to companies (www. bankier.pl). In July, a project for principles of good practices was remitted to consultations to the stakeholders of financial institutions. This is the frontier project aiming at unification of all types of crowdfunding activities and ensuring the safety of economic actors.

In Romania a number of 12 platforms are currently operating: 1) crestemidei.ro, 2)

multifinantare.ro, 3) wearehere.ro, 4) bursabinelui.ro, 5) kazuu.ro, 6) crowdfunding.alumni.ubbcluj.ro, 7) sprijina.ro, 8) potsieu.ro, 9) bursadefericire.ro, 10) galantom.ro, 11) doneazacuavon.ro, 12) startarium.ro/crowdfunding. There are also other platforms encouraging a certain behaviour, e.g. providing help for the needy or performing environmental actions. However, these will are not mentioned because they do not represent a tool to finance an activity.

Both fixed and flexible budget type of finance are used in Romanian crowdfunding. The Romanian platforms address different types of public, have different features and promote different projects:

- Two platforms are supported by important commercial banks

- One platform belongs to a university and raises money for in-house projects

- One platform intended to promote equity-based crowdfunding (the only one in Romania, but it is inactive in this respect)

- One platform is involved in charity medical projects

- One platform fights against cancer and domestic violence.

All the platforms above use the reward-based and/or the donation-based model. It is worth mentioning that, to the best of our awareness, no crowdfunding platform is actively involved in equity-based crowdfunding, nor in lending-based crowdfunding. 
The number of Polish platforms is double compared to Romania's, but so is the population. Despite the relative equal number of operating crowdfunding platforms per capita, the main conclusion is that Polish market allows for a more diversified activity in crowdfunding, while the Romanian activity is limited to its two basic forms, reward-based and donation-based crowdfunding.

\section{A Survey Analysing the Degree of Awareness about Crowdfunding in Poland and Romania}

A survey based on a self-administered questionnaire was conducted in two business faculties: the Faculty of Management of the University of Gdansk, Poland and the Faculty of Business Administration of the Bucharest University of Economic Studies, Romania in the period November 2018-January 2019.

The population considered for the survey was the total number of bachelor and master students in both faculties enrolled in full-time studies. The Polish faculty totals 1285 undergraduate students and 791 graduate students, i.e. 2076 students, while the Romanian faculty totals 876 undergraduate students and 404 master students, i.e. 1280 students. The sample for the Polish study included 185 respondents (of which 168 undergraduates and 17 graduates) and the Romanian sample included 202 respondents (of which 179 undergraduates and 23 graduates). Considering a 95\% confidence interval and 7\% margin error, both samples are representative.

Crowdfunding appeared ten years ago and in countries like Poland and Romania the concept has not been popularized enough. Hence, asking business students about crowdfunding was legitimate, given that within their academic syllabi and curricula include crowdfunding. In addition, being enrolled in management and business administration studies implies that some of the students would pursue a career in business, and that they would be up-to-date with the most recent FinTech solutions.

The respondents were grouped into two layers: the students who intend to start their own business (hereinafter referred to as those who are willing to do business) and the students who do not indent to have their own business (hereinafter referred to as those who are not willing to do business), as shown in Table 2.

Table 2 Willingness to do business

\begin{tabular}{|l|c|c|}
\hline & Poland & Romania \\
\hline Yes & 87 & 161 \\
& $47 \%$ & $79.7 \%$ \\
\hline No & 98 & 41 \\
& $53 \%$ & $20.3 \%$ \\
\hline Total & 185 & 202 \\
& $100 \%$ & $100 \%$ \\
\hline
\end{tabular}

Source: Authors' own research

As it can be noticed, the Polish respondents are almost equally distributed into the two categories, while the largest majority of Romanian respondents are willing to do business.

In terms of alternative sources of finance, the most preferred option both for Polish and Romanian respondents are: sponsorship/donation, followed by crowdfunding and public- 
private funds. The least preferred, but still in the same order for both Polish and Romanians, are business angels and venture capital, as shown in Table 3.

Table 3 Preferred alternative funding sources

\begin{tabular}{|l|c|c|}
\hline & Poland & Romania \\
\hline Crowdfunding & 34 & 63 \\
& $39.08 \%$ & $39.13 \%$ \\
\hline Business angels & 30 & 43 \\
& $34.48 \%$ & $26.71 \%$ \\
\hline Sponsorship/donation & 37 & 74 \\
& $42.53 \%$ & $45.96 \%$ \\
\hline Venture capital & 13 & 29 \\
& $14.94 \%$ & $18.08 \%$ \\
\hline Public-private funds & 34 & 59 \\
& $39.08 \%$ & $36.65 \%$ \\
\hline
\end{tabular}

Both those willing and those not willing to do business were asked to say whether they associated crowdfunding with donation. The argument for such a question is to assess the degree of knowledge about this alternative financing method. For both categories of respondents of both nationalities crowdfunding is associated with donation. Such an association reflects the undersized scope of crowdfunding and the little awareness of this funding method.

Experience with crowdfunding was investigated by means of a question asking whether the respondents had ever used crowdfunding to support a business, a project or a cause. Results indicate that roughly two thirds of those willing to do business never used crowdfunding, both for the Polish and for the Romanian respondents. The largest majority of respondents unwilling to do business have never used crowdfunding either $-89.90 \%$ of the Polish and $60.98 \%$ of the Romanians.

All respondents were asked whether they believe crowdfunding can be an efficient method to finance the projects developed by start-ups. The largest majority provided positive answers, while roughly $5 \%$ said crowdfunding is not effective. Once again, there is a consonance between the Polish and the Romanian answers, as can be seen from Table 4.

Table 4 Opinion about the effectiveness of crowdfunding in financing projects developed by start-ups

\begin{tabular}{|l|c|c|c|c|}
\hline & \multicolumn{2}{|c|}{ Poland } & \multicolumn{2}{c|}{ Romania } \\
\hline & $\begin{array}{c}\text { Willing to do } \\
\text { business }\end{array}$ & $\begin{array}{c}\text { Unwilling to do } \\
\text { business }\end{array}$ & $\begin{array}{c}\text { Willing to do } \\
\text { business }\end{array}$ & $\begin{array}{c}\text { Unwilling to do } \\
\text { business }\end{array}$ \\
\hline Yes & 69 & 74 & 112 & 32 \\
& $79.31 \%$ & $75.51 \%$ & $69.57 \%$ & $78.05 \%$ \\
\hline No & 5 & 4 & 5 & 2 \\
& $5.75 \%$ & $4.08 \%$ & $3.11 \%$ & $4.88 \%$ \\
\hline I do not know & 13 & 20 & 44 & 7 \\
& $14.94 \%$ & $20.41 \%$ & $27.33 \%$ & $17.07 \%$ \\
\hline Total & 87 & 98 & 161 & 41 \\
& $100 \%$ & $100 \%$ & $100 \%$ & $100 \%$ \\
\hline
\end{tabular}

In order to check the knowledge about crowdfunding, an additional specific question was included in the survey. The answers to this question are meant to identify respondents' perception 
concerning the efficiency of each type of crowdfunding model. Expectedly, the most numerous votes were in favour of the most common and known types of crowdfunding - i.e. reward-based and donation-based crowdfunding - , which could be explained by the popularity of the two in each of the two countries. Table 5 discloses the main perceptions regarding the efficiency of each model. The Polish and Romanian answers converge - the most frequent answers after the two above-mentioned types are, for equity-based crowdfunding. Background importance is afforded for lending-based and invoice trading crowdfunding by all respondents.

Table 5 Most efficient type of crowdfunding

\begin{tabular}{|l|c|c|c|c|}
\hline & \multicolumn{2}{|c|}{ Poland } & \multicolumn{2}{c|}{ Romania } \\
\hline & $\begin{array}{c}\text { Willing to do } \\
\text { business }\end{array}$ & $\begin{array}{c}\text { Unwilling to do } \\
\text { business }\end{array}$ & $\begin{array}{c}\text { Willing to do } \\
\text { business }\end{array}$ & $\begin{array}{c}\text { Unwilling to do } \\
\text { business }\end{array}$ \\
\hline $\begin{array}{l}\text { Donation-based } \\
\text { crowdfunding }\end{array}$ & 30 & 28 & 58 & 17 \\
\hline Reward-based & $34.48 \%$ & $28.57 \%$ & $36.02 \%$ & $41.46 \%$ \\
crowdfunding & 36 & 33 & 63 & 15 \\
\hline Equity-based & $41.38 \%$ & $33.67 \%$ & $39.13 \%$ & $36.59 \%$ \\
\hline Lending-based & 16 & 25 & 30 & 5 \\
crowdfunding & $18.39 \%$ & $25.51 \%$ & $18.63 \%$ & $12.20 \%$ \\
\hline Invoice trading & 2 & 8 & $5.11 \%$ & $2.44 \%$ \\
crowdfunding & $2.30 \%$ & $8.16 \%$ & 5 & 3 \\
\hline Total & $3.45 \%$ & 4 & $3.11 \%$ & $7.32 \%$ \\
\hline
\end{tabular}

The respondents were asked what the main benefits of using crowdfunding are. The purpose of this question was to check their current state of knowledge about crowdfunding benefits. Surprisingly and contrary to the previous questions, Polish and Romanian answers differed significantly. Results show that both categories of Polish respondents indicated "the money raised" factor as playing the highest importance. The majority of Romanian respondents willing to do business indicated "concept validation" on the first place. As concerns the opinion of Romanian respondents unwilling to do business, "the community created around the project, which will ensure sales after product launch" was indicated as the major benefit. "Concept validation" was indicated by $37.93 \%$ of the Polish willing to do business and by $40.82 \%$ of the Polish unwilling to do business as a second benefit regarding the use of crowdfunding.

All respondents were asked to identify main barriers faced by start-up owners. The majority of Polish (47.13\%) and Romanian (42.24\%) respondents willing to do business indicated that "the public is not aware of this funding method" is the barrier of highest importance. The barrier least indicated by Romanian respondents was that backers may change their mind and withdraw their contribution. On the contrary, Polish respondents willing to do business indicated as a barrier of minor importance that "project initiators find it difficult to decide what rewards to offer" (5.57\%), whereas Polish respondents unwilling to do business $(13.27 \%)$ indicated uncertainty related to project completion". The difficulty to design an attractive and convincing crowdfunding project and the public scepticism are the most frequent answers provided by Romanian respondents unwilling to do business. The latter is also shared by a large proportion of the Romanian respondents who are willing to do business (41.61\%). However, the respondents unwilling to do business do not seem to find the unclear legislation about crowdfunding an impediment to its proliferation (0\%).

Both categories of respondents were asked whether they believe crowdfunding will develop in their countries. The largest majority for both categories of respondents of both 
nationalities believe crowdfunding will develop in their countries. Once again, there is a consonance between Polish and Romanian answers.To sum up, Polish and Romanian opinions, attitudes and perceptions vis-à-vis crowdfunding largely coincide, with very few exceptions. Such answers imply that the degree of awareness about this new financing method is approximately the same for the two populations.

\section{Conclusion}

Based on findings above, Table 6 presents a synthesis of the main strengths and weakness of the two CEE crowdfunding markets, the Polish and the Romanian one, respectively.

Table 6 Strengths and weaknesses of the Polish and Romanian crowdfunding markets

\begin{tabular}{|c|c|c|}
\hline Country & Strengths & Weaknesses \\
\hline Poland & $\begin{array}{l}\text { New regulations introducing tax relief on the } \\
\text { commercialisation of innovation for companies } \\
\text { (starting 1st January 2019) } \\
\text { The limit for issuing shares in a company } \\
\text { without prospectus requirement was set to } \\
1,000,000 \text { Euro } \\
\text { Possibility of opening a simple joint-stock } \\
\text { resulting is increasing the elasticity in using } \\
\text { alternative funding source for companies* } \\
\text { In } 2019 \text { implementing principles of good } \\
\text { practices* }\end{array}$ & $\begin{array}{l}\text { Lack of an act regarding crowdfunding } \\
\text { activities } \\
\text { Lack of motivation and engagement in } \\
\text { crowdfunding projects resulting in the failure } \\
\text { of crowdfunding projects in their early stages } \\
\text { Many crowdfunding platforms are not able to } \\
\text { provide finance using crowdfunding } \\
\text { exclusively } \\
\text { Relatively limited awareness about } \\
\text { crowdfunding }\end{array}$ \\
\hline Rom & $\begin{array}{l}\text { A bill on crowdfunding was proposed, which } \\
\text { shows a certain degree of interest for this field }\end{array}$ & $\begin{array}{l}\text { Inexistence of a specially dedicated law for } \\
\text { crowdfunding } \\
\text { Relative lack of awareness of the public vis-à- } \\
\text { vis this new financing method } \\
\text { Only the most basic models of crowdfunding } \\
\text { - reward-based and donation-based - exist } \\
\text { and operate } \\
\text { Inflexible commercial legislation that does } \\
\text { not allow equity-based and lending-based } \\
\text { crowdfunding to take place }\end{array}$ \\
\hline
\end{tabular}

*estimated timeline Source: Authors' own research

The two countries are very similar in multiple regards: roughly the same "density" of operating crowdfunding platforms, inexistent specific legislation and comparable attitudes towards crowdfunding expressed by the young education population. However, the more flexible Polish market as well as its recent tax regulation development allow for a more diversified and dynamic evolution of the market, despite its obvious shortcomings.

Among the measures we propose in order to increase the performance and proliferation of crowdfunding financing we name the following: legislating crowdfunding in both countries, preferably in line with the FinTech European Action Plan; introducing tax 
reliefs for supporting innovations possibly financed through crowdfunding; amending the existing commercial legislation to allow for alternative financing methods to be effective increasing awareness about the concept of crowdfunding, and educating specialists and the general public in this respect.

The main limitation of the study is that the investigation of attitudes included only students. The research can be extended to other socio-professional and age categories to have a better idea about how popular and attractive crowdfunding is.

\section{References}

Baucus, M., \& Mitteness, C. (2016). Crowdfunding: avoiding Ponzi entrepreneurs when investing in new ventures. Business Horizons, 59(1), 37-50.

Farajian, M., Lauzon, A.J. \& Cui, Q. (2015). Introduction to a crowdfunded public-private partnership model in the United States. Transportation Research Record, 2530, 3643.

Gascon, J.F.F., Rodriguez, J.R., Monfonte, J.M., Lopez, E.S., \& Masip, P.M. (2015). Crowdfunding as a formula for the financing of projects: an empirical analysis. Revista Cientifica Hermes, 14, 24-47.

Hossain, M., \& Oparaocha, G.O. (2017). Crowdfunding: motives, definitions, typology and ethical challenges. Entrepreneurship Research Journal, 7(2), 20150045.

European Commission (2018). Crowdfunding. Retrieved from: https://ec.europa.eu/info/business-economy-euro/growth-andinvestment/financing-investment/crowdfunding_en.

European Commission (2017). Identifying market and regulatory obstacles to crossborder development of crowdfunding in the EU. Final report. Retrieved from:

https://ec.europa.eu/info/publications/171216-crowdfunding-regulatoryobstacles-crossborder-development_en

European Commission (2016). Crowdfunding in the EU Capital Markets Union. Commission Staff Working Document. Retrieved from: http://files.finantare.ro/2016/document2016-05-3-20972788-0-crowdfunding.pdf.

https://biznes.gazetaprawna.pl/artykuly/1390763,emilewicz-prosta-spolka-akcyjna-od2020-r.html

https://www.bankier.pl/wiadomosc/Pozyczki-spolecznosciowe-odzyja-Bedzie-europejskipaszport-7576618.html

Lower House (2015). Bill on the development of crowdfunding. Retrieved from: http://www.cdep.ro/proiecte/2015/800/00/1/se1008.pdf.

Maier, E. (2016). Supply and demand on crowdlending platforms: connecting small and medium-sized enterprise borrowers and consumer investors. Journal of Retailing and Consumer Services, 33, 143-153.

Mollick, E. (2014). The dynamics of crowdfunding: an exploratory study. Journal of Business Venturing, 29(1), 1-16.

Nucciarelli, A., Li, F., Fernandes, K.J., Goumagias, N., Cabras, I., Devlin, S. Kudenko, D., \& Cowling, P. (2017). From value chains to technological platforms: the effects of crowdfunding in the digital game industry. Journal of Business Research, 78, 341-352. 
Porlezza, C., \& Splendore, S. (2016). Accountability and transparency of entrepreneurial journalism. Unresolved ethical issues in crowdfunded journalism projects. Journalism Practice, 10(2), 196-216.

Renwick, M., \& Mossialos, E. (2016). Crowdfunding our health: economic risks and benefits. Social Science \&Medicine, 191, 48-56.

Statista (2018a). Alternative finance market in Europe from 2012 to 2016. Retrieved from:

PICBE | 193 https://www.statista.com/statistics/412255/europe-market-size-alternativefinance/.

Statista (2018b). Alternative finance reward-based crowdfunding volume in the Central and Eastern Europe (CEE)* region in 2016, by country. Retrieved from:

https://www.statista.com/statistics/612857/central-eastern-europe-countriesalternative-finance-reward-based-crowdfunding-volume/

Statista (2018c). Alternative finance market in Europe from 2012 to 2016. Retrieved from: https://www.statista.com/statistics/612861/central-eastern-europe-countriesalternative-finance-equity-based-crowdfunding-volume/.

Statista (2018d). Alternative finance real estate crowdfunding volume in the Central and Eastern Europe (CEE)* region in 2015 and 2016, by country. Retrieved from: https://www.statista.com/statistics/612896/central-eastern-europe-countriesalternative-finance-real-estate-crowdfunding-volume-by-country/

www.rp.pl 